\title{
GRA ZE ŚMIERCIĄ ISTOTA MECHANIZMU WŁADZY. O LOGICE TERRORU REŻIMU TOTALITARNEGO
}

\author{
THE GAME WITH DEATH IS THE ESSENCE OF THE POWER \\ MECHANISM. ON THE LOGIC OF TERROR \\ OF THE TOTALITARIAN REGIME
}

Justyna Grażyna Otto*

Państwo sowieckie w apogeum stalinizmu było w pełni rozwiniętym państwem totalitarnym. Marzenie o nowym człowieku, stanowiące istotę reżimu totalitarnego, zmieniło się w koszmar. Ten, kto znajdował się w orbicie Józefa Stalina, nie miał wyjścia: stawał się albo ofiarą, albo sprawcą. Jego władza absolutna wyrosła $z$ bezgranicznych rozmiarów terroru. Przemoc stalinowska była możliwa tylko dlatego, że Stalin i jego otoczenie traktowali ją jako oczywiste narzędzie służące umocnieniu władzy i przekonanie to pochodziło nie $\mathrm{z}$ tekstów europejskiego marksizmu, ale z doświadczenia i mentalnego ukształtowania sprawców. Stalin używał przemocy, kalkulując na zimno swoje posunięcia, gdyż grę ze śmiercią uważał za element mechanizmu władzy. Jednocześnie Stalin był mordercą, któremu zabijanie i zadawanie bólu sprawiało radość i który wykorzystywał argumenty ideologiczne, zapisane w kanonicznych tekstach teoretyków marksizmu,
\end{abstract}

At the height of Stalinism, the Soviet state was a fully developed totalitarian state. The dream of a new man, being the essence of a totalitarian regime, has turned into a nightmare. The man who was in the orbit of Joseph Stalin had no choice: he became either a victim or a perpetrator. His absolute power grew out of boundless proportions of terror. Stalinist violence was possible only because Stalin and his entourage treated it as an obvious tool for strengthening power, and this conviction came not from the texts of European Marxism, but from the experience and mental formation of the perpetrators. Stalin used violence to calculate his moves cold because he considered playing with death as an element of the power mechanism. At the same time Stalin was a murderer who enjoyed killing and inflicting pain and who used ideological arguments written in the canonical texts of Marxist theorists to justify his criminal decisions externally.

* Uniwersytet Warszawski, Wydział Nauk Politycznych i Studiów Międzynarodowych. 
do tego, by móc na zewnątrz uzasadnić swoje przestępcze decyzje.

Słowa kluczowe: reżim totalitarny; Józef Stalin; masowy terror; stalinizm; czystki; wróg
Keywords: totalitarian regime; Joseph Stalin; mass terror; Stalinism; purges; enemy

\section{WPROWADZENIE 1937 - ROK TERRORU}

Nikołaj Jeżow był jednym z siepaczy Józefa Stalina. W ostatnich latach wiernie wypełniał wszelkie polecenia dyktatora zarówno jako reżyser czystek partyjnych, demaskator spiskowców, jak i oskarżyciel z ramienia partii na procesach pokazowych. Był to brutalny, pozbawiony skrupułów przestępca, w którym energia i ambicje kryminalne szły w parze z niewolniczym oddaniem swojemu panu i mistrzowi - Stalinowi (Baberowski, 2014, s. 292, 293). Policja polityczna (Czeka, GPU), nieprawdopodobnie rozbudowana i bezwzględna w działaniu, stanowiąca, jak podkreślała klasyk badań nad reżimem totalitarnym, filozofka i teoretyk polityki Hannah Arendt, jądro władzy w kraju (2008, s. 592), nie była jednak wszechwładna, stanowiła tylko instrument w rękach Wodza, który stawiał przed plutonem egzekucyjnym jej szefów i cały legion ich podwładnych. Terror policyjny przez cały czas był czujnie kontrolowany przez Stalina. W tej dziedzinie wykazywał on szczególną pracowitość: chciał wiedzieć o wszystkim (Baszkiewicz, 1998, s. 359).

Żaden z najbliższych współpracowników Józefa Stalina nie bywał w biurze dyktatora tak często, jak właśnie jego „wierny pies” Jeżow w 1937 roku (Duraczyński, 2012, s. 307). I w owym roku - roku terroru - Stalin nie zajmował się niczym innym niż tylko sprawą represji i mordów. Przestał rządzić czy przestał rządzić inaczej. Chciał dokończyć dzieła zniszczenia.

Przewodnim hasłem stalinowskich represji była czujność. Długie lata działalności w polityce miały wykształcić w Stalinie przekonanie, że podziały w partii, rozbieżności ideologiczne i spory taktyczne były rezultatem działań szpiegów obcych sił politycznych. Siatka terroru miała zatem działać zarówno na zewnątrz, jak i wewnątrz partii. W 1937 roku Stalin wezwał do przekształcenia partii w „niezdobytą twierdzę”, odnosząc się w ten sposób do armii szpiegów, „burzycieli” i zdrajców w jej murach; „dwulicowców” należało zdemaskować i wytępić (Fainsod, 1967, s. 159). Wróg był zawsze na żołdzie obcych sił. Inspiratorem 
nagłej eskalacji terroru wobec wrogów był bez wątpienia właśnie sam Stalin (Overy, 2009, s. 197).W czerwcu tego roku, gdy terror osiągnął swoje apogeum, Jeżow - ten partyjny karierowicz, posiadający jedynie elementarne wykształcenie, za to całkowicie pozbawiony skrupułów i niewątpliwie także sumienia (Marples, 2011, s. 141) - każdego dnia kładł na biurku wodza protokoły przesłuchań oraz sprawozdania NKWD, doniesienia denuncjatorów i listy z nazwiskami funkcjonariuszy partyjnych i państwowych, przewidzianych do rozstrzelania. Dla Stalina nie było istotne, by aresztowania szpiegów i zdrajców oparte były na pewnych dowodach. Każdy mógł być zdrajcą i dlatego „organy” musiały zabić możliwie największą liczbę ludzi, by nie mógł ujść z życiem żaden potencjalny wróg. Terror szalał wszędzie. Dosięgnął nie tylko komunistów i generałów, ale niszczył wszystkie warstwy sowieckiego społeczeństwa. Rok 1937 nie był początkiem terroru, ale stanowił jego apogeum. Fala terroru rozchodziła się koncentrycznie z centrum władzy i kierując się na zewnątrz, obejmowała wszystkie warstwy społeczeństwa (Ciesielski, 2013, s. 224). Składały się na nią represje straszliwych lat 1937 i 1938: fizyczna eliminacja członków elity rządzącej, której nieśmiały początek przypada na próg lat trzydziestych, a która w grudniu 1934 roku, po zamordowaniu pierwszego sekretarza partii w Leningradzie Siergieja Kirowa stała się krwawą rzeczywistością; oczyszczanie partii z rzekomo nielojalnych funkcjonariuszy oraz wysokich urzędników na prowincji, rozstrzeliwanych od wiosny 1937 roku; masowe mordy kułaków, potomków przedrewolucyjnych elit, duchowieństwa, kryminalistów i ludzi spędzonych do łagrów między latem 1937 a jesienią 1938; aresztowania i mordowanie obcokrajowców i członków mniejszości etnicznych oraz ich masowe deportacje. Bezpieczny nie był nikt. W czasach stalinowskiej dyktatury każdy mógł nagle zostać uznany za wroga i aresztowany. Jak podkreślali George Urban i Robert B. Ulam w słynnej rozmowie: „Stalin osiągnął szczyt egalitaryzmu: każdy mógł paść ofiarą terroru... jedynie Stalin był nie zagrożony i w perwersyjnym odczuciu przeciętnego Rosjanina był w tym element swego rodzaju sprawiedliwości" (Rozmowy G. Urbana, 1987, s. 113).

Liczba aresztowanych, skazanych i rozstrzelanych na przełomie lat 1937/38 stanowiła jakościowy skok, eksces wśród ekscesów. Jednak to, co z roku 1937 czyni tak przerażającą datę, nie dotyczy tylko samej liczby ofiar. Chodzi o to, że jedynie nieliczni, których prześladowano i zamordowano, wiedzieli, dlaczego właśnie ich spotyka ten los (Schlögel, 2012, ss. 15,16).

Znak szczególny tej dyktatury stanowiło przecież to, że pozostawiała obywateli w niepewności, kto jest po właściwej, a kto po niewłaściwej stronie. Stalinizm budził przerażenie i strach, niszczył zaufanie i ćwiczył ludzi w ślepym posłuszeń- 
stwie. Totalitaryzm jest $\mathrm{z}$ natury swej agresywny i tak stworzone przez Józefa Stalina państwo, oparte na przemocy i gwałtach wymierzone było bezpośrednio w godność i życie człowieka. Arendt pisała o atomizacji społeczeństwa, o bezsilności i osamotnieniu ludzi w czasach dyktatur totalitarnych. Nikt nie potrafił skutecznie przeciwstawić się dyktaturom nowego typu, gdyż w stanie wyjątkowym i w atmosferze lęku, ludzie tracili siły i nie umieli zjednoczyć się przeciwko zdecydowanym na wszystko, pozbawionym skrupułów ludziom reżimu. Górujący nad społeczeństwem aparat reżimu i zdecydowanie jego członków, by w przypadkach najlżejszego oporu stosować gwałt i przemoc, powstrzymywały śmiałków przed podniesieniem ręki na władzę. „Superskuteczne i superkompetentne służby tajnej policji, decydujące o wszystkich przesunięciach we władzy" (Arendt, 2008, s. 592). Jak podkreślała Arendt (2014, ss. 494-496, 503, 497-500, 506-507), dążąc do uczynienia z ideologicznej fikcji rzeczywistości, co w istocie jest niemożliwe, totalitaryzm sam skazuje się na nieustanną walkę z wrogiem realnym oraz tzw. wrogiem obiektywnym, którym według arbitralnych decyzji dysponentów władzy politycznej, może w dowolnej chwili stać się każdy. Dopiero po wymordowaniu rzeczywistych wrogów i rozpoczęciu nagonki na „wrogów obiektywnych", terror staje się prawdziwą treścią reżimów totalitarnych (Arendt, 2008, s. 594). Masowy terror i walka z wrogiem powodują, że niezwykle ważną rolę w systemie władzy odgrywa właśnie tajna policja. W społeczeństwie uruchamia się mechanizmy wszechobecnego szpiegostwa i celem jest wytworzenie sytuacji, w której każdy może być agentem tajnych służb i wszyscy czują się stale nadzorowani (Bankowicz, Kozub-Ciembroniewicz, 2007, s. 197).

Niniejsza praca ma charakter ściśle politologiczny w wydaniu deskryptywno-analityczno-eksplanacyjnym i stanowi próbę prezentacji terroru jako kwintesencji reżimu totalitarnego z perspektywy interdyscyplinarnej, przy świadomym metodologicznie wykorzystaniu eklektyzmu politologii, gdyż tylko takie podejście daje nadzieję na osiągnięcie celu badawczego. A więc konfrontacja nade wszystko perspektywy teoriopolitycznej oraz perspektywy historii i psychologii polityki z akcentem na personalizację polityki. W poniższych rozważaniach, jako badacz problemu przywództwa politycznego, skupiam się na relacji dorobku klasycznej teorii polityki - przede wszystkim w wydaniu Hannah Arendt z egzemplifikacją reżimu totalitarnego w wydaniu państwa Józefa Stalina. Teza artykułu brzmi: Z klasycznego teoriopolitycznego punktu widzenia, terror stanowi kwintesencję totalitaryzmu, co jednak idealnie współgra z przekonaniami i osobowością jego twórcy. Reżim totalitarny w wydaniu radzieckim to stalinizm, a stalinizm to Stalin. Jak pisał Waldemar J. Dziak: „to Stalin stworzył stalinizm, 
a nie odwrotnie, choć prawdą jest, że dopiero system stalinowski dał mu władzę absolutną i wszechpotężną, zaś jego samego wykreował na cudotwórcę i półboga" (1990, s. 5).

\section{INSCENIZACJA STANU WYJĄTKOWEGO}

Rozkazy terroru wydawane przez dyktatora i jego klikę, postawiły Związek Sowiecki w permanentny stan wyjątkowy (Baberowski, 2009, s. 141). Władza Stalina opierała się właśnie na nieustannym inscenizowaniu stanu wyjątkowego. Tylko podczas wojny ze szpiegami, zdrajcami, sabotażystami, dyktator mógł przygotowywać swoich posłusznych współpracowników do wielkiego rozliczenia oraz psychicznego i fizycznego niszczenia wrogów. W atmosferze wszechobecnej przemocy także zwykli obywatele uczyli się, że problemy ze społeczeństwem władza rozwiązuje aresztowaniami, gwałtem i śmiercią. Ale obywatele już się nie bronili, gdyż ten, kto jest posłuszny, może liczyć na nagrodę, na przywileje i lepszą posadę. Ten, kto krytykuje lub się sprzeciwia, musi liczyć się z tym, że zostanie zamordowany. Nikt lepiej od Stalina nie zdawał sobie sprawy z tego, że siła dyktatury bolszewickiej opiera się na jej wielokrotnie dowiedzionej zdolności do straszliwego karania. Lęk przed represją znika, gdy sprawcy zaczynają mieć skrupuły. Gdy się wahają i zwlekają lub sprawiają wrażenie niezdolnych do działań bezwzględnych. Koszty oraz pożytki, płynące z przyjęcia postawy oporu, należało zatem wyważyć po obu stronach. Nikt nie odważyłby się na działania, których skutki były trudne do przewidzenia. Podporządkowani dyktatowi obywatele, którzy nie potrafią się zorganizować przeciwko władzy, będą przedkładać bezpieczeństwo wynikające $\mathrm{z}$ zachowania narzuconego porządku nad niewiadomą. Socjolog Heinrich Popitz podkreślał, że bezpieczeństwo wynikające $\mathrm{z}$ respektowania określonego porządku, może w tym sensie istnieć jedynie $\mathrm{w}$ ramach reżimu despotycznego, wspaniale łączy się ono $\mathrm{z}$ represjami i wykorzystywaniem obywateli. Jedynie w środowisku totalnej samowoli i niepewności, mała grupa ludzi trzymających władzę, może zmusić społeczeństwo do podporządkowania się logice przemocy i takim metodom postępowania, którym obce są wszelkie zasady etyczne. Bez atmosfery strachu i podejrzliwości nie byłoby możliwe, by pozbawieni skrupułów zbrodniarze, manipulowali lękiem i agresją milionów dla własnej korzyści (Popitz, 1992, s. 223).

Warto zadać następujące pytania badawcze: Dlaczego w sytuacji, gdy przestał istnieć jakikolwiek zorganizowany opór, reżim nie pozostał przy groźbach i nie 
stosował przemocy tylko w uzasadnionych przypadkach? Z jakiej przyczyny Stalin i jego pomocnicy kazali mordować miliony ludzi? Dlaczego mordowali wedle własnego uznania, bez żadnego planu, i niszczyli instytucje sowieckiego państwa? Czego spodziewał się dyktator i jego otoczenie od bezmiernej przemocy, na którą dano przyzwolenie w całym kraju? Teoria totalitaryzmu odpowiada na te pytania w sposób prosty i przekonujący: terror stalinowski był próbą rozprzestrzenienia lęku i przerażenia, by wprowadzić społeczeństwo w stan nieustannego pobudzenia i wyrwać z korzeniami wszelkie zalążki oporu. Pisali tak klasycy, jak przywoływana już Hannah Arendt czy Carl Joachim Friedrich. Cel ten można było osiągnąć jedynie poprzez coraz większe nasilenie przemocy, gdyż cechą państwa totalnego było, że stosowana przez nie przemoc przekraczała wszelkie miary. „Terror rządów totalitarnych przestał być wyłącznie środkiem zwalczania opozycji, chociaż jest stosowany także w tym celu. Terror staje się totalny wtedy, kiedy staje się niezależny od jakiejkolwiek opozycji; sprawuje absolutne rządy, gdyż nikt już nie stoi mu na drodze. Jeśli istotą władzy nie mającej charakteru tyranii są rządy prawa, a bezprawie jest istotą tyranii, to $\mathrm{w}$ takim razie terror jest istotą totalitarnego panowania" (Arendt, 2008, s. 651).

Wczesna typologia totalitaryzmu radzieckiego (zob. Friedrich, Brzeziński, 1956) oddaje dobrze charakter systemu, wyróżniając jako jedną z podstawowych cech monopol przemocy, charakterystycznie połączonej z terrorem jako głównym narzędziem kontroli społecznej. Oczywiście monopol przemocy istnieje w każdym suwerennym państwie, włącznie z państwami praworządnymi o reżimie demokratycznym. W państwach komunistycznych instrumenty przemocy nie były jednak podporządkowane prawu. Połączone z terrorem służyły niszczeniu tradycyjnych struktur. Stwarzając klimat strachu za pomocą odpowiednich mechanizmów, zapobiegały tworzeniu się autonomii i potencjalnych ośrodków opozycji. „Wrogowie reżimu” zasilali gigantyczną armię niewolników w systemie GUŁagu. Szczególną cechą aparatu przemocy była, prócz terroru, duża liczebność i zróżnicowanie organów przemocy, w skład których wchodziły: wojsko, służby paramilitarne oraz organy bezpieczeństwa, jak również prokuratura i sądownictwo. Były one całkowicie podporządkowane aparatowi partyjnemu, czyli kontroli cywilnej, co stanowiło zabezpieczenie na wypadek puczu. A aparat partyjny rozgrywał Józef Stalin. Istotę stalinizmu stanowiła „zaplanowana przypadkowość" terroru, który stosowany był losowo wobec jednostek i grup, włącznie z kierownictwem i aparatem partyjnym, niezależnie od ich faktycznej winy. Siało to strach i powszechną demoralizację (Rakowska-Harmstone, 2011, s. 210). 
Kontynuujmy stawianie pytań: Z jakiego powodu w 1937 roku zamordowano w łagrach dziesiątki tysięcy ludzi? Dlaczego Stalin kazał „usuwać” swoich krewnych i przyjaciół? Dlaczego zniszczył przywódców partyjnych i wojskowych? Dlaczego przemocą i gwałtami rządził przypadek? Dlaczego przyjaciele byli tak samo niszczeni jak wrogowie, a ostatecznie terror dosięgał także sprawców, tych samych, którzy stanowili jego koło zamachowe? Nie przekonuje teoria, która powołuje się na obawy Stalina przed zagrożeniem płynącym z zagranicy (Baberowski, 2014, ss. 231, 233).

Dla sadystów i niektórych psychopatów stan wyjątkowy jest rajem, gdyż redefiniuje on normalność i sprawia, że normalni ludzie czynią to, czego w innych warunkach nigdy by nie uczynili. Stalin był takim psychopatą (zob. Otto, 2012, ss. 129-131, 134-135, 137-138, 146-148, 155-159, 161-162, 168-170). Psychopatyczna mentalność Stalina dobrze pasowała do dyktatury i wojny. Obie sytuacje uwalniają siły destrukcyjne i pobudzają innych psychopatów i sadystów, by ujawnili to, co skrywali w sobie. Ich paranoidalne postrzeganie świata pomagało im nawet przeżyć w świecie gwałtu. Jak podkreśla Baberowski: to, co stwierdzają psychiatrzy zajmujący się zbrodniarzami psychopatami, odnosi się także do Stalina. Chłód uczuciowy, manipulowanie ludźmi, brak empatii i niezdolność do odczuwania współczucia $\mathrm{z}$ innymi i, jak pisał na temat psychogenezy masowych mordów, psycholog społeczny Rolf Pohl: „w ramach takiego postrzegania rzeczywistości i takich realnych wzorców zachowań, inni ludzie rzadko bywają dla psychopatów kimś więcej niż tylko obiektem" (Baberowski, 2014, ss. 233, 234).

Życiem Stalina był stan wyjątkowy. Dawał mu on możliwość przekształcenia sceny politycznej w scenę represji i przemocy. Można również stwierdzić, że Stalin był twórcą oraz beneficjentem stanu wyjątkowego, ponieważ pozwalał mu on nie tylko terroryzować społeczeństwo, ale też kontrolować i dyscyplinować swoich współpracowników. Jednak Stalin nie wykorzystywał represji wyłącznie do realizacji celów strategicznych. Zabijanie nie było dla niego żadnym problemem i gardził ludźmi, którzy wprawdzie mówili o potrzebie stosowania represji, ale którzy woleli nie narażać się na konsekwencje, wynikające ze stosowania gwałtu. Już w czasie wojny domowej kazał palić wsie i rozstrzeliwać ludzi bez powodu, gdyż znajdował upodobanie w stosowaniu przemocy wobec bezbronnych. Nigdy wcześniej nie był tak szczęśliwy, jak w latach wojny domowej, kiedy mógł być w pełni sobą (Baberowski, 2014, ss. 388-389).

Dla Stalina oraz „jego sługusów” przemoc była zawsze atrakcyjną metodą działania i czynili z niej użytek bez skrupułów. W atmosferze szalejącego bezprawia nikt nie mógł spać spokojnie. Podejrzliwość wobec każdego i wszystkich, 
stała się podstawową zasadą despotyzmu Stalina i wystarczyło jedno skinienie jego ręki, by wprawić w ruch dzieło zniszczenia całych instytucji. Panująca atmosfera paranoi sprawiła, że pomocnicy Stalina mogli aranżować historie, które $\mathrm{w}$ innych okolicznościach zostałyby uznane za absurdalne. W takich realiach potrzeba mordowania ludzi, jaką przejawiał Stalin, mogła rozwijać się swobodnie (Baberowski, 2014, s. 264). Jak konstatował George Urban: „można by napisać książkę Paranoja jako sposób rządzenia państwem; rządy Stalina dostarczyłyby dziewięciu dziesiątych materiału” (Rozmowy G. Urbana, 1987, s. 112).

Terror nie był oczywiście tylko ideą chorego umysłu Stalina. Stalin wykorzystał strategię przemocy fizycznej i psychicznej, by tak zastraszyć i wytresować elity partyjne i rządzące, by w przyszłości nie było już potrzebne wymuszanie na nich właściwych zachowań. I tak, po zakończeniu Wielkiego Terroru, nie musiał już zwoływać posiedzeń plenarnych Komitetu Centralnego, by informować o swoich planach. Każdy z członków KC wiedział z wyprzedzeniem, co należy robić, a czego robić nie można. W swoim osamotnieniu sekretarze partyjni na prowincji byli bezbronni wobec represji, pojęli zatem, że przetrwają, gdy $\mathrm{z}$ wyprzedzeniem będą odgadywać intencje Stalina, tak by nie wywołać cienia podejrzenia, że działają wbrew niemu.

\section{TERROR KONSTYTUUJE JEGO NIEPRZEWIDYWALNOŚĆ}

Jakiekolwiek jednak były motywy stalinowskich zbrodniarzy, czy było tak, jak twierdził Zygmunt Freud, że powody ideowe posłużyły destrukcyjnym żądzom jedynie za parawan (Freud, 1981, s. 21), to ważny pozostaje fakt, że gdy mechanizm terroru został uruchomiony, motyw przemocy tracił znaczenie, gdyż w logice despotycznych systemów władzy przemoc pociąga za sobą kolejne akty gwałtu, którym niepotrzebne są jakiekolwiek uzasadnienia i powody. Tego typu bowiem władza absolutna opiera się na sobie samej, nie jest środkiem do osiągnięcia celu, tylko celem samym w sobie. W „Ordnung des Terrors” Wolfgang Sofsky podkreślał, że władza, która musi się legitymizować, jest władzą słabą. „Władza absolutna nie jest posłuszna działaniu zorientowanemu na efekt. Jest pozbawioną celu praktyką negatywną, a nie działaniem wytwórczym, zmieniającym świat. Ideologia jest w tym wypadku nie tylko niepotrzebna, ale wręcz szkodliwa. Wiąże władzę z pewnymi celami i degraduje ją do zwykłego narzędzia. Terror jednak, który daje sobą kierować poprzez wyznaczanie celów, byłby przewidywalny. Nie byłby już terrorem" (Sofsky, 1993, ss. 32-33). Przemoc 
nie zależy od motywów, lecz od sytuacji stwarzającej możliwość jej zaistnienia (Baberowski, 2008, ss. 5-17).

Zdaniem Baberowskiego państwo stalinowskie potrafiło wykazać się siłą tylko w aktach przemocy i gwałtu oraz przykładowych aktach terroru, dokonywanych dla zastraszenia społeczeństwa, a jego skuteczność zależała od tego, czy wysocy urzędnicy państwowi na prowincji, potrafili wykonać polecenia płynące z dalekiej Moskwy. Państwo stalinowskie było słabe, a przemoc, którą stosowało, wypływała nie z jego siły, ale właśnie ze słabości. Stalinizm był ustrojem despotycznym, który nie dorastał do ambitnych zadań, jakie sam sobie wytyczył. Sięgał zatem po nieograniczoną przemoc, by osiągnąć to, co nie chciało dziać się samo z siebie. Po brutalnym procesie kolektywizacji i okresie wielkiego głodu wódz i jego zausznicy mieli wszelkie powody, by nie ufać społeczeństwu. Nie byli pewni swojej władzy, podejrzliwie traktowali nawet swoich protegowanych w regionach. Dlatego Stalin posyłał najbliższych współpracowników w wir wszystkich kampanii, wyznaczając im oraz niewydolnemu systemowi władzy zadania świadczące o ekstremalnych oczekiwaniach wodza. W takich sytuacjach miała szansę zatriumfować siła przemocy, niwecząc budzący się opór i wymuszając posłuszeństwo. Niepewność stała się cechą charakterystyczną ówczesnego życia. Wszędzie podsłuchiwali szpiedzy, wszędzie byli sabotażyści i zdrajcy oraz „społecznie szkodliwe elementy”. Nikt nie mógł się ustrzec przed podejrzeniami i dlatego stan wyjątkowy wydał plon w postaci posłuszeństwa przerażonych sterroryzowanych obywateli, którzy stawali się sprawcami, by nie stać się ofiarami (Reemtsma, 2008, ss. 179-180). W kampanii terroru chodziło o to, by „wszystkim zaszczepić pewną regułę zachowania, która miała z ludzi ukształtować dobrych obywateli dyktatury: lęk przed własnym myśleniem” (Arbatow, 1993, s. 59).

\section{KULT ZABIJANIA I SAMOPOŚWIĘCENIA SIĘ W IMIĘ LOJALNOŚCI}

Bolszewicy byli ludźmi przemocy, którzy publicznie inscenizowali kult zabijania, obsadzając siebie w roli potężnych macho. Chętnie korzystali z rekwizytów militarnych w postaci wojskowych butów, kabur na pistolety, czarnych skórzanych kurtek, uniformów. Wizerunek brutalnego macho wymagał też od nich brutalnego języka, jak również odrzucenia tolerancji, współczucia, empatii. Tworzył się świat oprawców i ofiar.

Nieuchronnym następstwem totalitarnych metod rządzenia jest zawsze pogarda dla prawa i wykorzystywanie przemocy do celów przestępczych. $\mathrm{Na}$ 
ogół, mówiąc o zbrodniach tamtego okresu, zwraca się szczególną uwagę na ludzi takich jak Gienrich Jagoda, Nikołaj Jeżow czy Ławrientij Beria. Ludzie ci, bez wątpienia, stanowili uosobienie nikczemności, cynizmu, duchowego i moralnego zwyrodnienia. Jak to się stało, że ludzie tego pokroju zajmowali tak wysokie stanowiska w socjalistycznym państwie? I tu należy stwierdzić, iż stalinowski aparat przymusu, $w$ formie, jaką przybrał pod koniec lat 30., nie mógł nie znaleźć "godnych" siebie wykonawców.

Postawienie resortu spraw wewnętrznych ponad prawem i narodem, brak elementarnej kontroli $\mathrm{z}$ dołu, a nawet $\mathrm{z}$ góry, musiało prędzej lub później przekształcić go w mechanizm tyranii jednego człowieka (Wołkogonow, 2006, s. 398). Wodza wszystkich narodów, o którym Boris Ilizarow w „Tajne życie Stalina. Według materiałów jego biblioteki i archiwum" pisze jako o osobie wielkiej i jednocześnie złej. Jest bowiem pewien, że bożyszcza ludzkości zawsze są mieszanką dużego uroku osobistego oraz nieograniczonej okrutności. Strach stanowi źródło ubóstwienia. Stalin miał być jego zdaniem politycznym katem, wyrafinowanym sadystą społecznym, ostrożnym i śmiałym intrygantem, który od początku był pewien swojego przeznaczenia i misji historycznej (Noskowa, 2011, s. 225).

Od swoich pomocników Józef Stalin oczekiwał bezwarunkowego podporządkowania oraz samopoświęcenia się w imię lojalności. Kto okazywał się nielojalny, naruszał kodeks honorowy męskiej grupy sprzysiężonych, znany Stalinowi z czasów młodości w Gruzji. Przyjaźń i osobista lojalność miały dla niego inne znaczenie niż dla bolszewików „europejskich”. Jego wyobrażenia o przyjaźni ukształtowały się w niepewnych czasach wojny i okrucieństwa, kiedy oznakę mądrości stanowiło niedowierzanie ludziom, których się nie znało i których nie można było sprawdzić. Kto sprzeniewierzył się wierności, tracił honor, gdyż zdradzał najwyższe dobro - niezłomną przyjaźń między mężczyznami. W Gruzji, ojczyźnie Stalina, przyjaźn i honor znaczyły coś innego niż w centrum rosyjskiego imperium. Przywódcy band rabusiów byli idolami Stalina, nie tylko dlatego, że działali wbrew autokratycznemu państwu i jego urzędnikom, ale także dlatego, że w oczach dorastających chłopców ucieleśniali ideał mężczyzny. Grupa bandycka stanowiła dla Stalina model władzy. Stalinowskie pojmowanie władzy bliskie było honorowemu kodeksowi mafii (Baberowski, 2014, ss. 332, 333, 389).

Wprawdzie czekiści mordowali ludzi tradycyjnie uważanych za wrogów, a zatem krewnych carskiej arystokracji, byłych opozycjonistów, kułaków i kryminalistów powracających $\mathrm{z}$ wygnania, ale w niektórych regionach nie było wiadomo, kogo uznać za wroga, a kogo za przyjaciela. A jeśli „zapasy ludzkie” 
się wyczerpały, kaci zmuszeni byli gdzie indziej szukać ofiar, by manifestować swoją lojalność.

Stalin stał się panem życia i śmierci, gdyż nikt nie śmiał mu się sprzeciwić. Jego przyjaciele stali się jego klientami, którzy nie mieli innego wyboru, jak tylko podporządkować się regułom swojego patrona. Idea wierności Stalina stała się ideą posłuszeństwa w związku mężczyzn, połączonych więzami lojalności. Tam jednak, gdzie wymaga się wierności, pojawia się też podejrzliwość i nieufność. Stalin nie mógł oczywiście oczekiwać od swoich pomocników, że oddadzą mu się do dyspozycji dobrowolnie i bezwarunkowo, a ich osobowości „rozpłyną się”. Aby zatem czynili to, czego od nich żądał, nastawiał ich wzajemnie przeciw sobie, powierzał im dokonywanie ciężkich zbrodni i tym samym, poddawał próbie. Tylko ten, kto był gotów złożyć dyktatorowi ofiarę, mógł zdobyć jego zaufanie. Stalin rozkazał, na przykład, aresztować kogoś z bliskich krewnych niemal każdego ze swych współpracowników. Właśnie on, ponieważ bez jego zgody ani Jeżow, ani Beria nie pozwoliliby sobie na taki krok. W pojęciu Stalina polityczna wola oznaczała gotowość do wszelkich ofiar w imię osobistego oddania tylko jemu. Gdyby ktokolwiek z otoczenia wodza próbował wystąpić w obronie swoich bliskich, okazałby niewybaczalną polityczną słabość (Wołkogonow, 2006, s. 395). W 1938 roku Stalin doprowadził przykładowo do samobójstwa żonę Jeżowa, zanim jeszcze jej mąż, wszechmocny wówczas szef NKWD, popadł w niełaskę. Po wojnie nawet Wiaczesław Mołotow musiał złożyć ofiarę. Kto przetrwał te psychiczne szykany, wymierzane przez dyktatora swojemu otoczeniu, dowodził, że wierność wobec wodza jest dla niego czymś ważniejszym niż związki i lojalność wobec własnej rodziny. Tylko ktoś, kto zachował niewzruszoną równowagę, mógł pozostać w gronie przyjaciół Stalina. Nikt nie wiedział z góry, co wódz uczyni i jak się zachowa - tak wobec zwolenników politycznych, jak i wobec przyjaciół i krewnych. Na tej niepewności i nieprzewidywalności kolejnych posunięć i decyzji, opierał się system stalinowskiego despotyzmu. Stalin kazał mordować nawet swoich bliskich krewnych (Baberowski, 2014, ss. 334-335).

W jaki sposób czekiści dawali sobie radę z procederem masowego zabijania? Dla zawodowych morderców, którzy nauczyli się katowskiego rzemiosła w NKWD, marzenia stały się rzeczywistością. Masowy terror dał im możliwość czynnego praktykowania nabytych umiejętności. Wykonawcy tego straszliwego dzieła nie musieli się do niczego zmuszać; pozostawali sobą, pozostawali mordercami tak długo, jak długo żądał od nich tego Stalin. W 1937 roku nie było odwrotu od zabijania ani dla psychopatów, ani dla karierowiczów. Kto raz splamił się krwią, musiał zabijać dalej, by samemu ujść z życiem. Wykonawcy zbrodni 
Stalina nie mieli wyboru. Zdawali sobie sprawę, że każdy z nich jako dzisiejszy oprawca może jutro stać się ofiarą. Ta prawda docierała do nich każdego dnia, gdy widzieli, jak zabiera się ich kolegów, jak się ich maltretuje i zabija, bo popadli w niełaskę, popełniwszy jakiś błąd. Atmosferę tę wytrzymywali jedynie najtwardsi z nich. Wielu czekistów załamywało się, dostawało pomieszania zmysłów lub odbierało sobie życie (Baberowski, 2014, ss. 361-362).

\section{TERROR JAKO OCZYSZCZAJĄCA BURZA}

Dla Krystyny Kersten istotą totalitaryzmu jest szczególna symbioza pomiędzy terrorem a ideologicznie motywowanym działaniem pozytywnym, w ramach której terror służy oczyszczeniu pola do budowy społeczeństwa doskonałego (1991, s. 7). Zarówno komunizm, jak i faszyzm, dwie ideologie, które zbudowały klasyczne reżimy totalitarne, doszły do władzy - jak zauważył Alain Besançon - „stawiając sobie za cel stworzenie doskonałego społeczeństwa poprzez wyeliminowanie źródeł zła” (1999, s. 14). Dla komunizmu oczywiście tym źródłem zła była własność prywatna i jej posiadacze. Realizacja programu ideologicznego i politycznego wymagała zastosowania przemocy, która została nie tylko usprawiedliwiona, ale nadano jej walor siły oczyszczającej. Besançon pisał: „Obie doktryny odwołują się do wzniosłych ideałów, zdolnych pobudzić do bezgranicznego poświęcenia i heroizmu, a równocześnie z obu wynika prawo, a nawet obowiązek zabijania" (1999, s. 14).

Wszak czystka to „historyczna misja o światowym znaczeniu”, indywidualna wina czy niewinność są wobec niej nieistotne (Fitzpatrick, 2017, s. 139).

W sposobie, w jaki przedstawiali to sami bolszewicy, terror stanowił metodę, dzięki której można było złamać opór i karać nielojalność. Był on „oczyszczającą burzą”, która uwalniała społeczeństwo od „społecznych śmieci” oraz „chwastów”, tylko częściowo wyplenionych w latach rewolucji kulturalnej i kolektywizacji. Urzeczywistniano system zbrodni, warunkujący w sposób niezbędny doskonałe społeczeństwo przyszłości. Narzędziem działania miał być terror niebywałych rozmiarów, który niby oczyszczający tajfun przetoczy się przez cały organizm państwa i dotrze do najodleglejszych jego zakątków tak, by żaden wróg nie mógł się ostać. Jednak dla sprawców przemocy cel stanowił sprawę drugorzędną. Wykorzystywali oni sytuację, pozwalając przemówić gwałtom, gdyż dyktatorowi podobało się, że ustanawiali kolejne rekordy w zabijaniu. Masowy terror zmienił życie sprawców i ofiar, stając się jeszcze jedną odpowiedzią na przemoc. Zmieniło 
się także znaczenie kary. Jeżeli władza karze z pierwszej lepszej przyczyny, bez wyraźnego powodu, kara traci swą moralną wagę. To, co każdemu może się przytrafić $\mathrm{w}$ dowolnej chwili, przestaje mieć charakter piętna, a staje się jedynie losem (Baberowski, 2014, ss. 236, 332).

Także wiara, że aparat partyjny oczyści się sam, nie leżała w naturze Stalina. Dyktator sprawdzał każdego, kogo podejrzewał, że uprawia swoją własną politykę i działa za jego plecami. Był w najwyższym stopniu czujny i ostrożny. Terror nie ograniczył się do partii i wojska, szalał także wśród urzędników państwowych, w szkołach i na uniwersytetach, w zakładach przemysłowych i organizacjach skupiających twórców. Dyrektorzy fabryk, menedżerowie i technicy umierali, gdyż byli powiązani z zamordowanymi przywódcami partii i zostali uznani za współodpowiedzialnych za niewypełnienie planów gospodarczych albo wypadki, spowodowane przeciążeniem maszyn i niekompetencją personelu. Wszędzie, gdzie sekretarze partii i funkcjonariusze aparatu państwa byli oskarżani i rozstrzeliwani, takie same represje dosięgały ich współpracowników. Logika stalinowska przewidywała, że wraz z patronem musi umrzeć też jego protegowany (Baberowski, 2014, ss. 325, 326). W całym państwie pokoje urzędników, zakłady przemysłowe zamieniały się w domy szaleńców, gdzie urzędnicy drżeli ze strachu i ze strachu przed aresztowaniem i śmiercią donosili na innych. Nie było dnia, żeby ktoś nie został aresztowany i już nie wracał. Urzędy pustoszały, a tym z funkcjonariuszy, którzy pozostali, nie zostawało nic innego, jak oswajać się z perspektywą śmierci. Niektórzy z przerażenia podupadali na zdrowiu, inni podejmowali próby samobójcze lub $\mathrm{z}$ rezygnacją czekali, co przyniesie los, jakby terror stanowił nieuchronny kataklizm natury, przeciw któremu wszelka obrona była daremna (Baberowski, 2014, s. 327). Jak pisała Arendt: „Terror jest urzeczywistnieniem prawa ruchu; jego zasadniczym zadaniem jest umożliwienie swobodnego oddziaływania na ludzkość sił przyrody czy historii, nie powstrzymywanych przez żadne spontaniczne działanie człowieka” (2008, s. 651).

Terror, który uderzył w oficerów Armii Czerwonej, przypominał żądzę krwi, a jego rozmiar przekroczył wszelkie wyobrażenie (Otto, 2015, ss. 215-222). Siły zbrojne niszczyły się same. Wciąż nowe oskarżenia i aresztowania (Duraczyński, 2012, ss. 290-294). Zatrzymywanych oficerów bestialsko torturowano, zamykano w tak ciasnych celach, że więźniowie $z$ trudem mogli zmieniać pozycję. Traktowano ich jak zwierzęta, ich organizmy niszczył szkorbut, wypadały im wszystkie zęby. Przesłuchiwanym łamano żebra, wybijano zęby, niektórzy czekiści pluli ofiarom w twarz lub załatwiali na nich swoje potrzeby fizjologiczne. Z korpusu oficerskiego nie pozostał prawie nikt. Ofiarą terroru padło 10000 oficerów 
(Suwenirow, 1998, ss. 137-138, 309, 338-341). Po 1938 roku zaczęli nią dowodzić młodzi, niedoświadczeni, zastraszeni oficerowie, obawiający się podejmowania samodzielnych decyzji.

Przytłaczającą atmosferę roku 1937 oddają sceny powtarzające się niemal we wszystkich domach, kiedy ludzie, $\mathrm{z}$ drżeniem nasłuchując przez drzwi swoich mieszkań odgłosów kroków na klatce schodowej, w napięciu czekali, czy NKWD zastuka do ich mieszkania czy też do mieszkania sąsiada. Człowiek stał się dla człowieka wrogiem. Nikomu nie można było wierzyć ani od nikogo spodziewać się pomocy. Ten, kto chciał pozostać przy życiu, za wszelką cenę był zmuszony unikać kontaktów z nieznajomymi. Mogło się bowiem zdarzyć, że nieznajomy okaże się prowokatorem albo zostanie nagle okrzyknięty wrogiem ludu. W Moskwie terror wywołał straszliwe spustoszenia, gdyż funkcjonariusze władzy pozostawali ze sobą w bliskich kontaktach, jak również mieszkali w niewielkiej odległości od siebie. Jeżeli jeden z nich został aresztowany przez organy bezpieczeństwa, wkrótce szły za nim dziesiątki innych urzędników, którzy znali aresztowanego lub z nim pracowali. Oczywiście Moskwa ucierpiała wskutek terroru bardziej niż jakakolwiek inna metropolia, ponieważ tu pracowała większość najważniejszych dla państwa urzędników i funkcjonariuszy. Tu również żyło wielu opozycjonistów z różnych republik sowieckich, odsuniętych przez lokalnych przywódców partyjnych (Baberowski, 2014, s. 328).

\section{WSZECHOGARNIAJĄCY LĘK ŚWIATA KATÓW I OFIAR}

Rok terroru dokonał straszliwych spustoszeń nie tylko w łonie partii i w środowisku urzędników państwowych, represje niszczyły także sam aparat NKWD. Pretorianie Stalina byli tak samo bezbronni, jak katowane i mordowane przez nich ofiary. Większość czekistów rekrutowała się bowiem z mniejszości narodowych: byli to przeważnie Żydzi, Litwini i Gruzini, którzy nie mieli się z kim sprzymierzyć po drugiej stronie władzy. Przed październikiem 1917 roku wielu czekistów było związanych z innymi partiami rewolucyjnymi, miało na sumieniu czyny dwuznaczne moralnie albo wręcz potworne przestępstwa. Stalin był świadom, że ludzie, którzy wywodzą się z mniejszości etnicznych, lub kryminaliści, którzy służąc kiedyś rewolucji, „umaczali po łokcie ręce we krwi”, nie odmówią teraz tego, czego od nich żądał. Będą mordować i brutalnie przesłuchiwać aresztowanych, bo nie mieli po prostu innego wyjścia. Lecz w ten sposób stawali się też, paradoksalnie, całkowicie uzależnieni od Stalina. Mógł on ich przecież 
unieszkodliwić pod zarzutem, że przed rewolucją byli wrogami proletariatu, a po rewolucji pracowali na rzecz obcych sił. Któż broniłby cyników bez przynależności politycznej i profesjonalnych katów, gdyby nadarzyła się okazja pozbycia się ich? I w ten sposób Stalin wiosną 1937 roku kazał przemówić terrorowi. Jeżow wymordował wszystkich współpracowników Jagody i zastąpił ich własnymi ludźmi oraz kazał aresztować tych czekistów w prowincjach, na których ciążyło podejrzenie, że mają związki z byłymi opozycjonistami. $\mathrm{W}$ ich miejsce przyszli wkrótce janczarzy nowego szefa NKWD, którzy mieli zresztą przed sobą ten sam dylemat, co ich aresztowani poprzednicy: jak wykonywać swoją pracę, by na koniec nie stać się, podobnie jak tamci, ofiarą represji (Baberowski, 2014, ss. 329-330).

Latem 1938 roku Stalin, działając zgodnie ze swym ulubionym scenariuszem, postanowił pozbyć się dotychczasowych wykonawców i obciążyć ich odpowiedzialnością za „wypaczenia”, „, samowolę”, „,nadużywanie władzy”. Miał zamiar postąpić tak samo, jak w przypadku kolektywizacji, kiedy oskarżył bezpośrednich realizatorów własnej polityki o wszelkie możliwe uchybienia. Stalin, który potrzebował kozła ofiarnego, wyznaczył tę rolę Jeżowowi (Wołkogonow, 2006, s. 395).

Dni Jeżowa były policzone, kiedy Stalin zakończył okres ,jeżowszczyzny”, jak w języku ulicy nazywano czas bezprzykładnego terroru. Nikt nie domyślał się latem 1937 roku, że Jeżow popadnie wkrótce w niełaskę satrapy. Wiosną 1938 roku gwiazda Jeżowa zaczęła powoli gasnąć. Już wkrótce lęk stał się także i jego stałym towarzyszem. Agonia polityczna Jeżowa ciągnęła się ponad rok. Także Beria, następca Jeżowa, był zbrodniarzem pozbawionym skrupułów, który otaczał się psychopatami i sadystami, torturującymi i zabijającymi w jego imieniu. Dla Berii nie było nic świętego. Wielbił jedynie przemoc. Często dawał upust swym sadystycznym skłonnościom, osobiście prowadząc przesłuchania, które nierzadko kończyły się tragicznie. Ten zwyrodniały morderca - a Stalin doskonale wiedział, co reprezentuje sobą jego ludowy komisarz spraw wewnętrznych (Wołkogonow, 2006, s. 399) - mordował przeciwników i konkurentów, sam strzelał do ludzi, gwałcił nieletnie dziewczęta, ale nigdy nie popełnił błędu, jakim było ukrywanie czegoś przed swym panem i mistrzem, Stalinem. Ten natomiast potrafił dobierać sobie takich ludzi (Tucker, 1990, s. 373).

Jaki wybór mieli tacy ludzie jak Jeżow czy Beria? Mordowali dla Stalina i jednocześnie przejmowali grozą innych stalinowskich aparatczyków. Bez ochrony Stalina jego etatowi oprawcy byliby narażeni na zemstę elity partyjnej. Nikt nie użalał się nad losem Jeżowa, nikt nie tęsknił za Berią, gdy Chruszczow kazał go zastrzelić w czerwcu 1953 roku. Stalin był genialnym strategiem - dopóki 
kryminaliści i psychopaci zabijali w jego imieniu, dopóty nikogo nie musiał się obawiać: ani swoich zaufanych, którzy czuli lęk przed czekistami, ani czekistów, którzy potrzebowali ochrony swego patrona, jak nikt poza nimi.

Bezprawiom lat 1937-1938, do czego sprowadza się w istocie działalność Stalina w owym czasie, przyświecał cel dalszej rozbudowy i umocnienia świątyni kultu jednostki, co jest tak charakterystyczne dla reżimu totalitarnego. W jego pojęciu nie było to sprzeczne z ideałami socjalizmu. Tu warto wspomnieć Karola Marksa i Fryderyka Engelsa, którzy krytykując teorię Thomasa Carlyle’a o prawie geniuszy i wodzów do przywództwa ${ }^{1}$, zauważyli przenikliwie, że nowa era, kiedy rządzi geniusz, różni się od starej ery głównie tym, iż kańczug uważa się za uosobienie geniuszu. Stalin nie mógł obejść się bez kańczuga. Kańczugiem tym jednak zakatowano już na śmierć tak wielu, że trzeba było znaleźć nowego wykonawcę. Należało zmieniać człowieka, który z woli Stalina uosabiał ów kańczug i kańczugiem się posługiwał (Wołkogonow, 2006, s. 394).

W drugiej połowie 1937 roku obiektem bezprzykładnych represji stały się także mniejszości etniczne - teraz stawali się agentami obcych sił, zagrożeniem dla bolszewickiego państwa.

\section{ZAKOŃCZENIE. KONIECZNE STRASZLIWE CRESCENDO PRZEMOCY}

Idee nie zabijają. I nie każdy, kto miałby ochotę kogoś zabić, jest w stanie wprowadzić w czyn wytwór swojej wyobraźni. Dopuszczający się przemocy ludzie, którzy znają się na zabijaniu, potrzebują idei jedynie po to, by usprawiedliwić swoją chęć zabijania przed tymi, którzy nie zabijają. Ani Stalinem, ani Jeżowem nie kierowały idee marksizmu, gdy wydawali rozkazy aresztowania, tortur, zabijania. Co prawda wielu wysokich funkcjonariuszy władzy uważało krwawy terror za działanie niezbędne, za chirurgiczny zabieg na ciele społeczeństwa, które mogłoby bez niego wymknąć się rządzącym spod kontroli², ale przemoc stalinowska była

1 „Władca ludzi, ten, którego woli nasza wola musi się poddać i oddać prawowiernie, znajdując w tym swoje dobro, może być uznany za najważniejszego $\mathrm{z}$ wielkich ludzi. Praktycznie stanowi on dla nas streszczenie wszystkich, różnorodnych form bohaterstwa; wszelka godność doczesna lub duchowna, na jaką tylko stać naszą wyobraźnię, wszelkie kapłaństwo i apostolstwo spoczywa w tym człowieku, wciela się weń, aby nami rządzić (...), aby nam powiedzieć, co czynić nam należy każdego dnia i w każdej godzinie. Nazywamy go (...) king, könning - co znaczy can-ning, człowiek zdolny" (Carlyle, 2006, s. 179).

2 Kiedy Mołotow na starość podzielił się swoimi przemyśleniami na temat wielkiego terroru lat 1937-1938, nadal utrzymywał, że były to działania konieczne do zapobieżenia wewnętrznemu kry- 
możliwa tylko dlatego, że Stalin i jego otoczenie traktowali ją jako oczywiste narzędzie służące umocnieniu władzy (Otto, 2015, ss. 256-260). I przekonanie to pochodziło nie z tekstów europejskiego marksizmu, ale z doświadczenia i mentalnego ukształtowania sprawców. Stalin używał przemocy, kalkulując na zimno swoje posunięcia, gdyż grę ze śmiercią uważał za element mechanizmu władzy. Nie tracił nad sobą kontroli, nie cierpiał na depresję, nie ulegał halucynacjom. Dręczenie innych sprawiało mu przyjemność (Baberowski, 2014, s. 387; Dziak, 1990, s. 104). Jak podkreślał Dziak: „Ciężko uzmysłowić sobie logikę stalinowską, gdyż ta w swej istocie nie jest logiką ludzką, nosi jakieś inne znamiona" (Dziak, 1990, s. 88).

Nic nie wskazuje na to, by Stalin działał z pobudek ideologicznych, wydając rozkazy zabijania funkcjonariuszy partii, urzędników i wojskowych. Wszystko natomiast zdaje się przemawiać za tym, że Stalin był mordercą, któremu zabijanie i zadawanie bólu sprawiało radość i który wykorzystywał argumenty ideologiczne, zapisane w kanonicznych tekstach teoretyków marksizmu do tego, by móc na zewnątrz uzasadnić swoje przestępcze decyzje. W kręgu najwyższych działaczy partyjnych wypowiadał się natomiast przeciwko represjom jako metodzie działania. Stalin był brutalnym mordercą, który stopniowo nasilał skalę represji, gdyż każde bezprawie rodziło następny gwałt. Jeżeli ktoś raz trafił do więzienia, gdzie poddawano go okrutnym torturom, miał nikłą szansę powrotu na wolność ponieważ, gdyby przeżył, stałby się żywym znakiem stalinowskiego okrucieństwa, przypominając dyktatorowi, że istnieją ludzie, którzy nigdy nie zapomną, jak z nimi postąpiono. Stalin nie zapominał nigdy, więc zakładał, że także inni odczuwają tak, jak on. W jego ojczyźnie ktoś, kto zabił, musiał liczyć się z tym, że krewni ofiary zemszczą się na nim. Sprawca mógł uniknąć krwawych porachunków tylko w sytuacji, gdy zabił wszystkich krewnych swojej ofiary lub w inny sposób uczynił ich niezdolnymi do walki. Tak samo wyobrażał sobie Stalin sposób traktowania wrogów ludu i ich krewnych. System brania zakładników i aresztowania całych rodzin stał się w latach Wielkiego Terroru częścią systemu strachu. Krewnych brano jako zakładników nie tylko po to, by wymusić zeznania na aresztowanych. Po śmierci ofiary nie kończyły się cierpienia żony, dzieci i dalszych krewnych (Baberowski, 2014, ss. 336-338).

Oczywiście ktoś, kto zadaje cierpienia i zabija wielu, musi liczyć się z zemstą. Gwałt niszczy zaufanie i poczucie bezpieczeństwa, ale ostatecznie rujnuje rów- 
nież suwerenność sprawcy ${ }^{3}$. Stalin nie mógł przestać działać metodą brutalnych represji, ponieważ gdyby ludzie przestali się bać, jego władza - władza despoty - byłaby zagrożona. Dlatego nie ufał kolejnym współpracownikom, otaczał się uzbrojoną ochroną, swoje dacze kazał otaczać kilkoma rzędami płotów, personel domowy angażował osobiście, na przyjęciach zmuszał zaproszonych gości, by pierwsi kosztowali przygotowanych potraw. W pewnym momencie przemoc jako metoda działania Stalina znalazła uzasadnienie w fakcie, że ona właśnie była jedynym gwarantem jego samowładztwa (Baberowski, 2014, s. 388). Styl rządów Stalina opierał się na podejrzliwości.

Władza absolutna Stalina wyrosła $\mathrm{z}$ bezgranicznych rozmiarów terroru. Kiedy funkcjonariusze i urzędnicy donosili na siebie nawzajem i z lęku tracili zdrowie, Stalin mógł odgrywać rolę pana życia i śmierci każdego obywatela. Bohdan Szklarski podkreśla, że strategiczny wymiar przywództwa totalitarnego to także możliwość wskazywania wrogów-odszczepieńców, będących przyczyną wad rzeczywistości, w jakiej żyją obywatele. W tym sensie przywództwo totalitarne jest od czasu do czasu odnawiane: czystki eliminują wszystko, co złe, następuje powrót do źródeł, odnowienie wspólnoty, swoiste ładowanie akumulatorów. Porażki i sukcesy mają więc w totalitaryzmie charakter spersonalizowany, z tym że te pierwsze idą na konto podwładnych, a te drugie upiększają wizerunek wodza jako jedynego nieomylnego (Szklarski, 2011, s. 39).

Terror nie oszczędzał ani komunistów, ani bezpartyjnych, ani robotników, ani chłopów. Terror stalinowski charakteryzował się niesłychanym rozmiarem oraz tym, że objął zarówno wrogów, jak i przyjaciół. Zgadzam się ze słowami Sheili Fitzpatrick, że być może „nigdy nie uzyskamy ostatecznej odpowiedzi na pytanie, co miała na celu wielka czystka”, ale „z pewną dozą pewności można powiedzieć tyle, że jeżeli stała za nią jakaś konkretna polityczna intencja, to była to intencja Stalina"(2017, s. 140).

To, co z początkiem roku 1937 rozpoczęło się jako krwawe „samooczyszczanie się" partii, doprowadziło do zorganizowanego mordu. Postępowanie Stalina charakteryzowała eskalacja metod. Aż do zimy 1938 roku trwało torturowanie i mordowanie ludzi, a Józef Stalin nie uczynił nic, by przerwać ten proceder, przeciwnie - ta apokalipsa narodziła się w centrum władzy i przez nie była kie-

3 O pilnujących Kremla oficerach NKWD Stalin powiedział: „Widzicie, ilu ich tu jest? Idziesz korytarzem i za każdym razem się zastanawiasz: który? Jeśli ten, to strzeli ci w plecy, jeśli ten za zakrętem, to w twarz. Idziesz i myślisz o tym". M. Łobanow (red.), Stalin w wospominanijach sowriembnnikow i dokumientow epochi, Moskwa: Eksmo, 2002, s. 361. 
rowana. Stalin i jego pretorianie nadzorowali przebieg działań i wywierali presję na lokalne organy partyjne i służby bezpieczeństwa, zmuszając je do ekstremalnej „wydajności”. Masowe mordy nie były dziełem lokalnych satrapów, którzy swoje strategie eksterminacyjne podpowiedzieli władzy centralnej. Było to dzieło Stalina, który w dodatku był zdania że to, co wywołał, stanowiło oczyszczającą burzę. Trwało uprzątanie ziemi ze śmieci (Baberowski, 2014, ss. 378-379).

W warunkach stworzonych przez Stalina, próba stworzenia nowego człowieka poprzez fizyczne zniszczenie ludzi starego systemu, oznaczała masowy mord. Stalin przekształcił „jednopartyjną dyktaturę” w „reżim totalitarny” i uczynił ze Związku Radzieckiego, po 1937 roku, sterroryzowane państwo policyjne. Richard Pipes charakteryzował państwo sowieckie w „apogeum stalinizmu” jako „w pełni rozwinięte państwo totalitarne" (2005, s. 292). Marzenie o nowym człowieku, stanowiące istotę reżimu totalitarnego, zmieniło się w koszmar. Ten, kto znajdował się w orbicie Stalina, nie miał wyjścia: stawał się albo ofiarą, albo sprawcą. Trzecim wyjściem było samobójstwo. Psychopata zamienił olbrzymi, zamieszkały przez 150 milionów ludzi kraj w jeden wielki dom wariatów. Zbudował system, w którym dzieci donosiły na rodziców, w którym państwo kontrolowało nie tylko czyny, lecz i myśli swoich obywateli, gdzie skazańcy w ostatnich słowach wychwalali swoich katów.

\section{MORDERCZA TRIADA}

Co skłoniło Stalina do potwornych zbrodni? Czy on oraz jego otoczenie myśleli, że osiągną cel swoich marzeń, kiedy oczyszczą kraj z wrogów? Jednak fakt, iż terror trwał także w latach II wojny światowej, a nawet po jej zakończeniu, wydaje się przemawiać przeciw takiej interpretacji motywów działania wodza. Prawdopodobnie Stalin osiągnął po prostu to, co zamierzył: nikt nie mógł się mu sprzeciwić, funkcjonariusze drżeli ze strachu, a młodzi karierowicze byli posłuszni, ponieważ zawdzięczali wszystko śmierci starej elity. Źródła możliwego buntu zostały skutecznie unicestwione. Jakież cele mógł mieć teraz Stalin oraz jego dwór? Przemoc nie powinna była stracić swojego niecodziennego charakteru, ponieważ jej efekt - przerażenie, można osiągnąć jedynie za sprawą nagłości i zaskoczenia. $\mathrm{Ci}$, którzy przeżyli, powinni przypominać sobie terror i pamiętać, że w każdej chwili może powtórzyć się to, co się działo.

Józef Stalin stosował permanentny terror i masowe represje jednocześnie dlatego, że tylko takie postępowanie stanowiło emanację jego osobowości. Był 
twórcą terrorystycznej metody sprawowania władzy w partii i państwie. System stalinowski stał się wyrazem skrajnej formy sowieckiego totalitaryzmu. W jego ZSRR permanentnie przeprowadzano czystki ${ }^{4}$ (Mawdsley, 2012, ss. 129,130). W ich wyniku specjalne trybunały oraz trojki organizowały zbiorowe egzekucje (Malia, 1998, s. 297). System stalinowskich represji przyjmował niewyobrażalne rozmiary: „6 milionów zgonów w rezultacie klęski głodu z lat 1932-1933, którą należy w znacznym stopniu przypisać polityce przymusowej kolektywizacji i łupieżczemu zagarnianiu przez państwo kołchozowych plonów; 720 tysięcy egzekucji, z czego ponad 680 tysięcy jedynie w latach 1937-1938 z wyroku „sądu” specjalnego GPU-NKWD; 300 tysięcy potwierdzonych zgonów w obozach między 1934 a 1940 (jeżeli mowa o okresie 1930-1933 nie mamy dokładnych danych, lecz posługując się ekstrapolacją Courtois et al. wnioskują, że w ciągu całego dziesięciolecia liczba zgonów wyniosła 400 tysięcy. Nie wliczono tu niemożliwej do sprawdzenia liczby zmarłych między aresztowaniem a rejestracją na „wejściu” przez biurokrację obozową); 600 tysięcy potwierdzonych zgonów zesłańców, osób „przemieszczonych” i osadników specjalnych; około 2,2 miliona zesłańców, osób „przemieszczonych” i osadników specjalnych; skumulowana liczba 7 milionów „osadzeń” w obozach i koloniach w latach 1934-1941, z zastrzeżeniem, że nie mamy wystarczająco dokładnych danych dla lat 1930-1933" (Courtois et al., 1999, s. 199).

Związek Radziecki w latach 1937-1938 był areną straszliwego crescendo przemocy. Dyktator miał reagować na rzekomy wzrost zagrożenia działalnością spiskową. Dla Stalina miał to być końcowy etap walki klasowej przeciw rodzimym terrorystom oraz obcym potęgom. Wielki, mający własne interesy aparat bezpieczeństwa powiązany z partią i dyktatorem, umożliwiał odniesienie zwycięstwa nad spiskowcami. Było to zadanie, nad którym pracowano, zanim jeszcze padł rozkaz eskalacji działań. Stalin, jak podkreśla Nikołąj Kapczenko, zapisał jedną z najczarniejszych stron historii, jej treść przeraża okrucieństwem, skalą, a czasem brakiem sensu (Noskowa, 2011, s. 226). W Związku Radzieckim aparat bezpieczeństwa nie był jednak żadnym abstrakcyjnym bytem, lecz częścią społeczeństwa. Eskalacja przemocy wymierzonej we „wrogów” była rezultatem głębokiej i niebezpiecznej symbiozy między przywódcą, policjantami oraz społeczeństwem (Overy, 2009, ss. 221, 228-229). „Stalin, stalinizm, stalinowcy to

4 Zdaniem Allana Bullocka, zasadnicza czystka wystąpiła w latach 1936-1939 i objęła kolejno likwidację: eksopozycjonistów, stalinowców-rewolucjonistów z lat 1929-1933, leninowców - partyjnych i bezpartyjnych z elit gospodarki, armii i kultury, a nawet NKWD (Bullock, 1994, t. 1, s. 521). 
triada nieodłącznie związana ze sobą, wzajemnie się przenikająca i uzupełniająca. Scementowana krwią, bezprawiem, samowolą i wspólnym interesem" (Dziak, 1990, s. 5). Opłakując śmierć tak wielu niewinnych ofiar, nie wolno zapominać o tym, że Józef Stalin uczynił biernymi współuczestnikami swoich zbrodni miliony ludzi, którzy uwierzyli, że „tak trzeba” ${ }^{5}$. Represje na ogromną skalę były możliwe dlatego, że „wódz” wywołał społeczną inercję przemocy, której towarzyszyły donosicielstwo, brak zasad, wszechobecne kłamstwo, oszczerstwa. Naród radziecki był zakładnikiem terroru. Nawet po grozie Wielkiego Terroru lat 30. społeczeństwo sowieckie nie zaznało spokoju. Trwający trzydziesci lat stan wyjątkowy dobiegł końca dopiero 5 marca 1953 roku, gdy umierał Stalin. Jak słusznie rekapituluje Baberowski: „Stalinizm i terror są synonimami. Najgłębszą treść stalinowskiego panowania stanowiło ciągłe stosowanie bezmiernego gwałtu" (2009, s. 7).

\section{BIBLIOGRAFIA:}

Arbatow, G. (1993). Das System. Ein Leben im Zentrum der Sowjetpolitik. Frankfurt am Main: S. Fischer Verlag.

Arendt, H. (2008). Korzenie totalitaryzmu. Warszawa: Wydawnictwa Profesjonalne i Akademickie.

Arendt, H. (2014). Korzenie totalitaryzmu. Warszawa: Świat Książki.

Baberowski, J. (2008). Gewalt verstehen, Zeithistorische Forschungen, 5(1), 5-17.

Baberowski, J. (2009). Czerwony terror. Historia stalinizmu. Warszawa: Wydawnictwo Naukowe PWN.

Baberowski, J. (2014). Stalin. Terror absolutny. Warszawa: Prószyński i S-ka.

Bankowicz, M., Kozub-Ciembroniewicz, W. (2007). Dyktatury i Tyranie. Szkice o niedemokratycznej władzy. Kraków: Wydawnictwo Uniwersytetu Jagiellońskiego.

Baszkiewicz, J. (1998). Powszechna historia ustrojów państwowych. Gdańsk: Wydawnictwo ARCHE.

Besançon, A. (1999). Myśmy wszystko zapomnieli. Gazeta Wyborcza, 118, 22-23 maja. Bullock, A. (1994). Hitler i Stalin. Żywoty równoległe. t. 1. Warszawa: PIW, Wydawnictwo Bellona.

Carlyle, T. (2006). Bohaterowie. Cześć dla bohaterów i pierwiastek bohaterstwa w historii. Kraków: Wydawnictwo Zielona Sowa.

Ciesielski, S. (2013). Wróg jest wszędzie. Stalinowska polityka represyjna w latach 1928-1941. Toruń: Wydawnictwo Adam Marszałek.

5 Klasyk teorii totalitaryzmu J.J. Linz pisał o niekwestionowalnej moralnej racji terroru, którą podzielają w reżimie totalitarnym nie tylko rządzący, ale całe społeczeństwo (Linz, 2000, ss. 102-108). 
Courtois, S., Werth, N., Panné, J.-L., Paczkowski, A., Bartosek, K.,Margolin, J.L., Kauffer, R., Rigoulot, P., Fontaine, P., Santamaria, Y.,Boulouque, S. (1999). Czarna księga komunizmu. Zbrodnie, terror, prześladowania. Warszawa: Pruszyński i S-ka.

Duraczyński, E. (2012). Stalin. Twórca i dyktator supermocarstwa. Pułtusk-Warszawa: Akademia Humanistyczna, ASPRA-JR, Bellona.

Dziak, W.J. (1990). Stalin. Stalinizm. Stalinowcy. Warszawa: SOW ZSP Alma-Press.

Fainsod, M. (1967). How Russia is ruled. Cambridge, Massachusetts: Harvard UP.

Fitzpatrick, S. (2017). Zespół Stalina. Niebezpieczne lata radzieckiej polityki. Wołowiec: Wydawnictwo Czarne.

Freud, S. (1981). Warum Krieg? (list do Alberta Einsteina). W: S. Freud, Gesammelte Werke. t. 16. Werke aus den Jahren 1932-1939. Frankfurt am Main.

Friedrich, C. J. i Brzeziński, Z. (1956). Totalitarian Dictatorship and Autocracy. Cambridge, Mass.: Harvard UP.

Kersten, K. (1991). O użyteczności konceptu totalitaryzmu w badaniach historii PRL. W: A. Paczkowski (red.). Czy PRL była państwem totalitarnym? Stenogram konwersatorium $z$ dn. 19.XII. 1990 r. Warszawa.

Linz, J.J. (2000). Totalitarian and authoritarian regimes. Boulder, Colo., London: Lynne Rienner Publishers.

Łobanow, M. (red.). (2002). Stalin w wospominanijach sowriembnnikow i dokumientow epochi. Moskwa: Eksmo.

Malia, M. (1998). Sowiecka tragedia. Historia komunistycznego imperium rosyjskiego 1917-1991. Warszawa: Philip Wilson.

Marples, D.R. (2011). Historia ZSRR. Od rewolucji do rozpadu. Wrocław: Wydawnictwo Zakład Narodowy im. Ossolińskich.

Mawdsley, E. (2012). Czas Stalina. Warszawa: BELLONA.

Noskowa, A. (2011). Nowoczesna historiografia rosyjska wobec stalinizmu $w$ ZSRR - próba podsumowania. W: J. Szymoniczek, E.C. Król (red.). Czas totalitaryzmu. Stalinizm, faszyzm, nazizm i pokrewne systemy polityczne w XX wieku (ss. 218-230). Warszawa: Instytut Studiów Politycznych PAN. Collegium Civitas.

Otto, J.G. (2012). Przywódca polityczny elementem konstytutywnym reżimu politycznego. Toruń: Wydawnictwo Adam Marszałek.

Otto, J.G. (2015). Wojsko $w$ reżimie politycznym - zarys analizy politologicznej. W: J.G. Otto (red.). Demokratyczne i niedemokratyczne rezimy polityczne (ss. 200-228). Warszawa: Dom Wydawniczy ELIPSA.

Otto, J. G. (2015). Chory reżim polityczny. Patologie w polityce w świetle jej personalizacji. W: J.G. Otto (red.). Demokratyczne i niedemokratyczne reżimy polityczne (ss. 256-285). Warszawa: Dom Wydawniczy ELIPSA.

Overy, R. (2009). Dyktatorzy. Hitler i Stalin. Warszawa: Wydawnictwo Dolnośląskie.

Pipes, R. (2005). Rosja bolszewików. Warszawa: Magnum.

Popitz, H. (1992). Phänomene der Macht, Tübingen: Mohr.

Rakowska-Harmstone, T. (2011). Stalinizm - sedno i interpretacje. W: J. Szymoniczek, E.C. Król (red.). Czas totalitaryzmu. Stalinizm, faszyzm, nazizm i pokrewne systemy 
polityczne w XX wieku (ss. 206-217). Warszawa: Instytut Studiów Politycznych PAN. Collegium Civitas.

Reemtsma, J.-P. (2008). Vertrauen und Gewalt, Versuch über eine besondere Konstellation der Moderne. Hamburg: HIS Verlag.

Resis, A. (red.). (1993). Molotov remembers: inside Kremlin politics. Conversations with Felix Chuev. Chicago: Ivan Dee.

Schlögel, K. (2012). Terror i marzenie. Moskwa 1937. Poznań: Wydawnictwo Poznańskie. Sofsky, W. (1993). Die Ordnung des Terrors, Das Konzentrationslager. Frankfurt am Main: S. Fischer Verlag.

Stalin i stalinizm. Rozmowy George'a Urbana. (1987). London: Polonia Book Fund.

Suwenirow, O. (1998). Tragedija RKKA 1937-1938. Moskwa.

Szklarski, B. (2011). Model przywództwa totalitarnego w ujęciu porównawczym. W: J. Szymoniczek, E.C. Król (red.). Czas totalitaryzmu. Stalinizm, faszyzm, nazizm i pokrewne systemy polityczne w XX wieku (ss. 30-42). Warszawa: Instytut Studiów Politycznych PAN. Collegium Civitas.

Tucker, R. C. (1990). Stalin in Power. The Revolution from Above 1928-1941. New York: W. W. Norton \& Company.

Wołkogonow, D. (2006). Stalin. Wirtuoz kłamstwa, dyktator myśli. Warszawa: Wydawnictwo Amber. 